\title{
National piety: Religious equality, freedom of religion and national identity in Finnish political discourse
}

\author{
Titus Hjelm*
}

School of Slavonic and East European Studies, University College London, Gower Street, London WC1E 6BT, UK

This paper analyses the legislative discourse regarding a Members' Initiative to enact a law which was discussed in the Finnish parliament in 2006 and which proposed changes to the constitution and several laws, the purpose of which was to balance the privileged position that the Lutheran Church of Finland enjoys. The author uses critical discourse analysis to examine four different discourses emerging from the debate: inequality of religions in the eyes of the law; the 'completeness' of the freedom of religion in Finland; the justified hegemony of the 'folk church'; and the church as a value base in a pluralising world. He argues that the discursive struggle between the different positions is a struggle between 'minimalist' and 'maximalist' definitions of freedom of religion and that the discussion represents a case of 'national piety', a conflation of discourses of religious equality, freedom of religion and national identity that reproduces the status quo.

KEY WORDS critical discourse analysis; Finland; folk church; freedom of religion; ideology; national identity; religious equality; state church

We have come in this country to tolerate many [ ... ] fixed opinions, or national pieties, each with its own baffles of invective and counterinvective, of euphemism and downright misstatement, its own screen that slides into place whenever actual discussion threatens to surface. (Didion 2003, 24)

In 2005 two Green ${ }^{1}$ MPs, Rosa Meriläinen (Tampere) and Irina Krohn (Helsinki), submitted a Members' Initiative to enact a law in the Finnish parliament, with an aim to 'strengthen the freedom of religion and religious equality of citizens' (LA 157/2005 vp). ${ }^{2}$ The initiative proposed changes to the constitution, criminal law, two education acts and several other laws, the purpose of which was to balance the privileged position that the Evangelical Lutheran Church of Finland enjoys.

\footnotetext{
*Email: t.hjelm@ucl.ac.uk

${ }^{1}$ The official English-language name of the party is The Greens of Finland.

${ }^{2}{ }^{\prime} \mathrm{AA}^{\prime}$ stands for lakialoite (Member's Initiative) and 157/2005 vp is the official diary number of the initiative.
} 
Although the initiative never made it to voting stage because of the election of a new parliament in 2007 (initiatives do not carry over to the next parliament in the Finnish system), the preliminary debate in the plenary session provides a fascinating case for analysing the dynamics of legislative discourse as well as for examining the interconnectedness of discourses of freedom of religion, religious equality and national identity. My aim is to find out how religious equality is articulated in Finnish political discourse, how the different discursive constructions can be understood in light of the social and political context and what the effects of these constructions are. In addition to being an example of empirical analysis of religion and political discourse in a national context where a church or several churches receive preferential treatment (e.g., the Nordic Countries, Greece, Germany, Ireland, etc.; see Fox 2008, 114), I wish to contribute to the broader sociology of religious pluralism, where the focus is on 'political secularisation', i.e., the 'macro-separation of church and state' (Turner, Possamai, and Barbalet 2011). The article's approach is, I would argue, distinct from the mainstream literature, where argumentation tends to be based on policies and policy outcomes rather than the policymaking process itself (e.g., Barbalet, Possamai, and Turner 2011; Michel and Pace 2011; Monsma and Soper 2009).

For example, in a case that is close to mine - Sweden - Gustafsson (2003) argues that 'the change of relations between the church and the state' (51) that culminated in the public declaration of 'separation' in 2000 was an outcome of a long process. His main sources are special committee reports which he contextualises in the party affiliations of committee members. In addition, he makes some conclusions regarding the originally church- (and religion-)hostile stance of the Social Democrats (the party in power for most of the 20th century) and its effects on the process. Finally, he contextualises the process in the attempts of the church to respond to an increasingly secular public sphere. ${ }^{3}$ Nowhere, however, is there any discussion of the actual arguments used in defending a particular position, how and in what kind of language the reports were discussed in the parliament. Although a valuable contribution in many other ways, Gustafsson's analysis is exemplary of a lacuna in research: there is little to no discussion of the discursive construction of the premises of action, that is, of the reasons for supporting or opposing a particular policy. In the case of church-state relations and religious pluralism, this means that we don't know what the arguments and rhetoric for and against are and, most importantly, whether questions of church and religion more broadly are discussed as 'religious' matters in the first place. From a discursive perspective on political secularisation, the political discourse can be very secular even if the outcome of the political debate is not - and vice versa. As my case study shows, 'religion' itself is not necessarily at stake at all when discussing the reproduction of church-state relations and approaches to freedom of religion. In other words, the kind of micro-level discursive approach to religion and politics that I'm advocating here is indispensable if we understand contemporary parliamentary politics as 'government by speaking' or 'government by discussion' (Palonen 2008, 82;

\footnotetext{
${ }^{3}$ See also Anderson (2009), who discusses the development of party systems and the church's role in the development of the Swedish welfare state through the lack of religious cleavage (cf. Germany) and both the church and state's interests in nation-building. Again, we learn about party politics and the putative effects of church doctrine, but little about the actual discourses or discursive struggles that might explain why particular positions were adopted.
} 
see e.g., van Dijk 1997). In the study of religion, Winnifred Sullivan's (2005; Burns et al. 2008) 'courtroom ethnography' comes close to my approach, although the 'rules' of parliamentary discourse and the textual sources are different, of course. This article is also an empirical contribution to the emerging field of discursive study of religion (Granholm 2013; Moberg 2013; Taira 2013; von Stuckrad 2010). Finally, in addition to the sociology of religious pluralism and church-state relations, this paper represents a contribution to a critical sociology of religion that pays serious attention to social inequality, including religious inequality, and which, as I have argued elsewhere, is currently underrepresented in the sub-discipline. An exception is McKinnon (2012), who employs a similar framework for ideology critique as I do in this article.

I will examine, using critical discourse analysis (CDA), the discourses of the parliamentary debate. My primary data source is a transcript of the preliminary discussion in the Finnish parliament on 15 February $2006 .{ }^{4}$ The discussion includes 20 speeches of various lengths by eight MPs. In addition, I will refer to the original initiative (lakialoite) text, but mainly for the purposes of cross-referencing MP Krohn's responses in the discussion, where she reiterates the main points of the initiative.

Four different discourses - ways of speaking - emerge from the debate: inequality of religions; the 'completeness' of the freedom of religion in Finland; the justified hegemony of the 'folk' church; and the church as a value base in a pluralising world. ${ }^{5}$ I argue that the discursive struggle between the different positions is a struggle between 'minimalist' and 'maximalist' definitions of freedom of religion (cf. Lincoln 2003, 5). I also argue that the issue of religious equality in Finland is a case of 'national piety' (as American essayist Joan Didion puts it in the epigraph), an issue that: (1) when discussed, problematically conflates discourses of religious equality, freedom of religion and national identity; and (2) is rather not discussed at all in the political arena, mostly because, I argue, of a 'folk church' ideology. These factors effectively reproduce the status quo and function ideologically by doing so.

\section{The social and political context of the LA 157/2005 vp initiative}

Like the other Nordic countries (Denmark, Iceland, Norway, Sweden), Finland has a strong national Lutheran Church. Although independent Finland officially became religiously neutral with the implementation of the Freedom of Religion act of 1922, the Evangelical Lutheran Church of Finland retained a special legal status, which in international comparison warrants the title 'state church' (Chaves and Cann 1992; Christensen 1995; Fox 2008, 115; Heikkilä, Knuutila, and Scheinin 2005, 527; Robbers 2005) - despite the widely spread apologetic claiming

\footnotetext{
${ }^{4}$ The diary number for the plenary debate is PTK 8/2006 vp. The transcript can be found online at http:// www.eduskunta.fi/triphome/bin/akxhaku.sh?lyh=PTKSUP?lomake=akirjat/akx3100 $\rightarrow$ Asian tunnus: LA 157/2005 $\rightarrow$ Hae] [Accessed 14 July 2012].

${ }^{5}$ These discourses emerge from various discussions of individual amendments in the initiative, but mostly regardless of and/or in addition to the particular amendment suggestions. That is why it makes more sense to analyse the material in the framework of broader discourses than individual law amendments. The reason the comments from the floor don't necessarily even refer to the actual proposals has to do with the nature of the preliminary debate (where no decisions regarding amendments can be made), but also, in my opinion, because of MP Räsänen's strong contextualisation of the initiative as an attack on the church in the beginning of the discussion.
} 
that 'the state church is changing into a folk church', as if the latter somehow negates the former (Seppo 1998; 2003; Sihvo 1991, 21). ${ }^{6}$ In addition to the legal status, the church is, for example, financed by a 'church tax' collected by the state from the members of the church. Despite a recent update of the Freedom of Religion Act (in 2003), the status of the Lutheran Church remained unchanged. In fact, because the Lutheran Church's status is defined separately, the LA 157/ 2005 vp initiative suggested changes to a number of laws, including the constitution, but not the Freedom of Religion Act itself. The proposal was not all about the Lutheran Church, although that ended up being the gist of the preliminary debate analysed here. The proposed changes to the Education Acts, which suggested either religious studies common to all students (after the Swedish model) or moving the content of religion classes to other existing curricula (e.g., history, philosophy), would have affected all religious communities that have an approved curriculum for teaching their own religion in state schools. Similarly, the proposal to change all marriages into civil marriages would have affected all those religious communities that have such a right (although not their right to bless marriage after civil registration). Overall, although minor amendments have been made to laws pertaining to church-state relations throughout the years, the LA 157/2005 vp initiative represents the most comprehensive challenge to the state church system since the drafting of the constitution and the original Freedom of Religion Act in the immediate years after Finland's independence in 1917. It can be easily characterised as a radical initiative in the Finnish context. ${ }^{7}$ As such, one could have thought that the initiative would have been widely discussed in the media and heatedly debated in parliament, ending in a dramatic vote.

None of this happened. Instead, as Rosa Meriläinen wrote in a personal communication to me, 'the initiative went to initiative heaven, that is, nothing happened to it' (email to author, 14 December 2009). In order to understand the nigh-on non-existent impact that the initiative eventually had, I need to briefly discuss the legislative process in Finland.

Legislative proposals in Finland are presented to Parliament in the form of Government bills or Members' initiatives. ${ }^{8}$ Any individual member of parliament can propose an initiative proposing the enactment of a law. As these initiatives may be proposed at any time, they are a highly popular form of activity for parliamentarians as they allow them to demonstrate to the electorate their areas of interest and that they are working to advance various causes. Each year between 150 and 200 initiatives are submitted. However, only a very small proportion of these are actually accepted and even fewer become law. The majority are rejected or not dealt with at all beyond the preliminary debate.

\footnotetext{
${ }^{6}$ The Orthodox Church in Finland enjoys some of the same privileges as the Lutheran Church (such as state-collected church tax), although its status is not defined in the constitution. The Orthodox Church is pertinent in the case of the Education Acts and the provisions on public broadcasting, where it is separately mentioned and is mentioned in the actual debate, but always in conjunction with the Lutheran Church.

${ }^{7}$ Despite the fact that the signatories left out perhaps the most significant issue, the church tax, because 'religious communities do important social work' (Krohn 2006).

${ }^{8}$ For an outline of the legislative process see the Parliament home pages: http://web.eduskunta.fi/ Resource.phx/parliament/aboutparliament/legislativework.htx [Accessed 14 July 2012].
} 
Initiatives for the enactment of a law are first presented to parliament in a preliminary debate in a plenary session. During the plenary debate, no decisions are taken on the substance of the proposal; it is largely a technical procedure to determine to which one of the parliament's subject-specific special committees the initiative should be referred. Only after the relevant special committee has produced a report on the initiative, can it go forward to be handled in plenary session. Most initiatives fail to make it further than this initial committee stage and many are 'left on the table' at the committees, which effectively voids them if the process is not finished by the tenure of the current parliament, as initiatives don't carry on to the next - as was eventually the case with LA 157/2005 vp.

However, the plenary-session discourse is nonetheless interesting because of the outcome of this case. Pekonen $(2008,213)$ writes that 'public talk in plenary sessions is not primarily addressed to other parliamentarians ... the main audience is the general public, the media and the voters'. Although from some MPs' point of view the hard work of parliament is conducted in the 'professional' parliamentary committees (Pekonen 2008, 214; cf. Wodak 2008, 16), the plenary is a forum for articulating broader politics in addition to individual policies. These articulations - discourses - are in turn an interesting reflection of broader social positions. Below I outline how discourse, and political discourse in particular, can be analysed contextually and with a focus on the formation of ideology.

\section{Analysing political discourse: A methodological note}

My analytical 'toolkit' is based on critical discourse analysis (CDA) as formulated by Norman Fairclough (especially 1992; 1995) and John Richardson (2007). It also draws from Fairclough's latest work on 'political discourse analysis' (Fairclough and Fairclough 2012), although selectively. I will pay attention to the generic limitations and particularities of parliamentary debate (see Wodak 2008, 14-19), but the focus will be on the discursive construction of the premises of action, that is, of the reasons for supporting or opposing the proposed initiative.

My textual analysis follows Richardson's suggestion that textual analysis in CDA should proceed from the microanalysis of words, through sentences onto 'larger-scale analysis of the organisation of meaning across a text as a whole' (2007, 46-47). Put schematically, the progression looks like this (Table 1):

The analysis begins with words, which contextualise events and actors, and ends with the analysis of narrative, or the ways in which a coherent story is told. In between I situate the analysis of transitivity, modality, presupposition and rhetoric. Briefly explained, transitivity describes the processes depicted in discourse and the

Table 1. The process of textual analysis in CDA

\begin{tabular}{ll}
\hline Micro-textual analysis & Macro-textual analysis \\
Structuring of propositions & Combining propositions \\
Words & Rhetoric \\
Transitivity & Narrative \\
Modality & \\
Presupposition & \\
\hline
\end{tabular}

Source: Adapted from Richardson (2007). 
relationships between participants in these processes. Richardson $(2007,57)$ argues that the analysis of transitivity is the key to understanding representation of actions in discourse. Especially important is the masking or deletion of agency through passive sentence construction. Modality, in turn, refers to the ways in which the 'speaker or writer is committed to the claim that he or she is making' (Richardson 2007, 59). This is similar to what Goffman (1981) calls 'footing', referring to the 'range of relationships that speakers and writers have to the descriptions they report' (Potter 1996, 122). Modality is usually indicated by the use of modal verbs (e.g., may, could, should), their negations (e.g., couldn't, shouldn't) and adverbs (e.g., certainly). Analysing presupposition means looking at the tacit assumptions made in texts. ${ }^{9}$ Finally, the analysis of rhetoric examines the argumentative and persuasive aspects of text (see also Palonen 2008; Reisigl 2008).

Although presented here in schematic form, my contention is that there is no mechanical way of doing CDA (cf. Wijsen 2013). Considering the potential breadth of the apparatus, it would not only be impractical, but also constraining to focus on every possible linguistic detail at the expense of interpretive vigour. As Fairclough's (and others') work shows, there is always a balance between the formal and interpretive aspects in the most illuminating discourse analyses.

The role of interpretation is most obvious in the identification of different discourses (in the plural). This identification rests on contextual knowledge and cannot be mechanical (Burr 1995, 174-175). For example, I could have talked about two discourses only: the one for changing the status quo, the other against. Or, made a distinction between discourses that construct the 'facts' of the situation, as opposed to discourses that construct what the situation should be like (see below). But making distinctions between discourses is more than outlining common-sense categories or 'thematising'. As Fairclough $(1992,128)$ puts it:

[A] discourse is a particular way of constructing subject-matter, and the concept differs from its predecessors [e.g., 'topic'] in emphasizing that contents or subject-matters - areas of knowledge - only enter texts in the mediated form of particular constructions of them. It is helpful in this regard to choose terms for particular discourses which designate both the relevant area of knowledge, and the particular way in which it is constructed.

This premise, and the research questions, have guided my choice of discourses. It is possible, likely even, that someone else might end up with a different set of discourses, but that does not make the discourse analysis 'faulty' in any sense. Rather it is part of the reflexive process. The important point to remember is that the distinctions are less about what a particular discourse 'says', and more about what it does.

Unlike some other forms of discourse analysis, CDA doesn't stop at textual analysis. In addition, CDA examines 'the dynamics of power, knowledge, and ideology that surround discursive processes' (Phillips and Hardy 2002, 20), with a focus on ideology and hegemony. The critical conception of ideology can be concisely defined as 'meaning in the service of power' (Thompson 1990, 8). Speaking in the plural, Fairclough defines ideologies as 'constructions of reality (the physical world, social relations, social identities), which are built into various dimensions

\footnotetext{
${ }^{9}$ See Richardson $(2007,63-64)$ for examples of how these are achieved linguistically.
} 
of the forms/meanings of discursive practices, and which contribute to the production, reproduction or transformation of relations of domination' (Fairclough 1992, 87). When 'proper' ways of thinking about and doing things are constructed from a particular perspective, giving a one-sided account that ignores the complexity of social life, discourse is said to function ideologically (Chouliaraki and Fairclough 1999, 26). Hegemony is the peak of ideology, the point when alternative constructions are suppressed in favour of one dominating view.

The methodological implications of the critical conception of ideology are twofold. First, the focus is on how different aspects of language use contribute to one-sided constructions of things, ideas or events that serve the interests of particular social groups. This is 'meaning in the service of power' in action. As a further twist, it is equally important for CDA to study what is not said, that is, what we take for granted. According to Fairclough, any reference to 'common sense' is 'substantially, though not entirely, ideological' (Fairclough 1989, 84, emphasis in original). Because common sense naturalises our conceptions of everyday life, it is the most effective way of sustaining hegemony, that is, an exclusive interpretation of reality. From a broader perspective, 'being critical' in CDA means paying special attention to the 'naturalisation of inequality and neutralisation of dissent' (Richardson 2007, 6). Perceived inequality being the premise of this case study, the CDA framework is well suited to the task of tackling the questions posed above.

\section{Inequality of religions and the role of the state}

The 'justifications' section of the LA 157/2005 vp initiative outlines its rationale by describing what the (signatories think the) current state of affairs in Finland is:

Freedom of religion includes three principles: the right to practice religion, the right to not participate in the practice of religion, and that the public authorities

have to treat all religions and worldviews equally. Except for the last, these principles are fulfilled in Finland reasonably well. ${ }^{10}$

The gist of the initiative is, then, to show - in categorical language typical of legislation - how religions are currently unequal in Finland because of the privileged status of the Lutheran and Orthodox churches. Hence, the aim of the initiative is to 'strengthen freedom of religion and the religious equality of citizens' (emphasis added).

The preliminary debate on 15 February 2006 opens with a lengthy response to the initiative, which I will discuss in the next sections. But MP Krohn, who ended up being the only one espousing this discourse (the other signatory, MP Meriläinen was absent from the plenary) then spends her first response (and most of the two others) in further explaining the rationale of the initiative. The gist of it is, Krohn says:

Our initiative really comes from the principle that freedom of religion includes three elements: the right to practice one's religion, the right to not practice one, and a third element, that the public authorities treat all religions equally. In Finland, these first two elements have been applied really well and this last element, that is, the attitude or position of the public authorities towards religions

\footnotetext{
${ }^{10}$ All translations are the author's. I have retained grammatical errors but have not added the usual sic.
} 
is not equal. That is the spirit, if you will, of this initiative. The spirit is not against religions, including Christianity, but instead the aim is to draw attention to the fact that at the moment the state takes a stand on which god and which conception of god is right, if you will, and I think this may have hazardous consequences.

Here Krohn repeats the gist of the initiative, but - compared to the initiative itself in a defensive language, which is explained by the fact that this is a response to a long critique of the initiative discussed in the next section. Krohn uses hedging strategies throughout: the two first elements of freedom of religion are said to apply 'really well' (as opposed to 'reasonably well' in the initiative) and the spirit of the initiative is said not to be against religions.

In addition to the construction of the religious situation in Finland as unequal, there are two additional points that set Krohn's discourse apart from all the other MPs, and which become the focus of the subsequent discussion. Her narrative emphasises that equality is best achieved by following international examples and making religion a private matter. The 'justifications' section of the initiative text starts with the words: 'In the European tradition religion is a private matter that the state should respect and protect.' This invokes an international precedent for the case, but also assumes - rather problematically - that there is (a) a common 'European tradition' of religion, and (b) that in this tradition religion is a private matter. In the discussion itself, she offers many examples of international precedents and privatisation: the proposed changes to the education acts are already implemented 'in a couple of other Nordic countries', 'in America, the American state, or the United States, does not have religion, but it believes in god', and perhaps most importantly, 'in France already a hundred years ago, because there were such bitter quarrels between Protestants and Catholics, they took the situation $(\text { tilanne })^{11}$ [sic] that the public authorities are neutral in their relation to religions, and are secular'. Also, mid-February 2006 saw the Danish Muhammad cartoon crisis (which was invoked by several MPs) spreading to Finland when Suomen Sisu, a far-right organisation, published the controversial cartoons on their website. Interestingly, considering that religious pluralisation in Finland and Europe in general is mostly a matter of accommodating growing Muslim populations, Krohn raises the 'Europeanness' of this initiative (which, to her credit, is in line with the opening words of the initiative):

It has been also highlighted in the publicity on this initiative that we, together with others, as an European constitutional state, have issued a challenge to Islamic states, in some of which, one can say, a very theocratic model of governance exists, in which the church and the state are very close to each other.

In sum, strengthening freedom of religion through religious equality is a matter of privatising religion in the LA 157/2005 vp. The representation of the unequal situation is mostly devoid of actors - naturalising the representation as something given - but Krohn, more than any other MP, emphasises that it is 'our' (the MPs') responsibility to make this change. The categorical language of the initiative itself is balanced by Krohn's hedging in the actual debate, where she says that 'it might be better for all of us that the position of religion is a matter of a person's

\footnotetext{
${ }^{11}$ Krohn probably means 'position' here, but the Finnish word she uses is tilanne (situation).
} 
private life', or 'it may be that this initiative is not the best possible' (emphases added). On a less textual level Krohn uses footing to boost her rhetoric in two opposite ways. On the one hand, as noted above, this is not a personal issue for her, not an anti-religious issue, but a matter of updating Finland's legislation to conform with international standards. On the other hand, she evokes personal language that could be directly from a 'strict separationist' argument in the American discourse on church-state relations (e.g., Davis 2011). Krohn talks about how her grandfather left the church 'because in his opinion spiritual life belongs to the private sphere and the state should not be used as a crutch in such an important thing as relationship with god' (emphasis added). She repeats: '[I] would wish that we could trust that Christianity and this religion truly carries itself without us public authorities making such, as I said, crutches.'

That argument, however, did not carry the day in the parliament that February 2006.

\section{'Complete' freedom of religion}

The opening response to LA 157/2005 vp was made by the Christian Democrat leader Päivi Räsänen, an outspoken Christian known for her active participation in all matters related to religion in the parliament. Her response is by far the longest and, based on the style and comparison with the other turns in the debate, the only one prepared in advance. She tackles all the proposed amendments and presents all of the main discourses discussed here in her first response, but in this section I will concentrate on the argued 'completeness' of the freedom of religion in Finland. This discourse is a 'factual' counter discourse to the 'inequality of religions' discourse of the initiative, that is, it tries to show that the premises of the initiative are false when it comes to freedom of religion in Finland. I quote the beginning of Räsänen's turn in length:

Dear Mister Speaker! MPs Meriläinen and Krohn are proposing a long list of measures in this initiative, which could in different ways weaken the influence of the Church, churches, and Christian cultural heritage in Finnish society. [...] The objective of this initiative is right as such, however. That is, $[\ldots]$ to strengthen the freedom of religion and the citizens' religious equality, but I think it is done in quite the wrong way in this initiative. [...] Pekka Hallberg, president of the supreme administrative court, has stated about the connection between state and church that since its birth, our republican Constitution included a fundamental change to the relations between church and state. Our Constitution was based on the principle of the freedom of religion and did not acknowledge the significance of the Lutheran faith as state ideology anymore. [... ] Elsewhere, Martin Scheinin has stated in the book 'Perusoikeudet' (Basic Rights) that our implementation of the legal status of the Lutheran and Orthodox churches is not against the Freedom of Religion Act.

In Räsänen's contextualisation, the point of the initiative is to 'weaken the influence of the Church, churches, and Christian cultural heritage' (emphasis added) - quite different from the preamble to the initiative, which claims (see above) to 'strengthen freedom of religion and the religious equality of citizens' (emphasis added). Although Räsänen positions herself as a supporter of freedom of religion and religious equality in the next two sentences, the contextualisation is a negative one (anti-church and anti-Christian) because of the way the initiative purports to 
drive freedom of religion and religious equality by privatising religion. She goes on (in the first and subsequent responses) to expand on the issue of 'Christian cultural heritage' (see below), but first lays down the constitutional and legal 'facts'.

By referring to two legal experts, Räsänen distances herself from the issue ('footing') and represents the constitutional and legal situation with the voice of outside authority. The message is that, from this perspective, a 'complete' freedom of religion already exists: the Lutheran Church is not privileged, because it is not a state church (anymore) and because 'our implementation of the legal status of the Lutheran and Orthodox churches is not against the Freedom of Religion Act'.

In terms of freedom of religion, the two stances can be summarised as 'maximalist' and 'minimalist': the signatories of the initiative clearly explicate that although the freedom to practise religion and the freedom not to practise religion are mostly well established in Finland, the freedom of religion can't be complete as long as some religious communities are privileged in law and in the constitution. From the minimalist point of view and Räsänen's - she was the only one of the MPs to employ this type of 'factual' discourse - as long as the state does not require adherence to a particular religion, freedom of religion is complete. The justification for the 'complete' freedom position in the speeches of the MPs opposing the initiative is provided by the discourse of the 'folk' church, which practically takes over the discussion after Räsänen's first response.

\section{'Folk' church, democracy and Christian heritage}

If the inequality discourse and the opposite 'complete' freedom of religion discourse are mostly about constructing the 'facts' of the Finnish situation (the 'ideational' function of discourse; Fairclough 1992, 64), the discourses on the 'folk' church and values - although intertwined with the ideational function - can be characterised as fulfilling both the 'identity' and 'relational' functions (Fairclough 1992, 64). That is, they are less about defining what the legislative situation is like than defining what Finnish society is like and what is should be like. Päivi Räsänen sums up the idea in her long opening response: 'The state is not denominational in itself, even though the Lutheran Church and also the Orthodox Church have the status of folk church.' The term 'folk church' gained widespread credence in academic and public discourse especially after the passing of the 1922 Freedom of Religion Act, which was considered to have severed the churchs-state connection for good (e.g., Juva 1960). As such its use in the LA 157/2005 vp debate continues an established tradition. The 'folk' status of the church is constructed in three distinct ways: symbolically; through an appeal to democracy; and by equating 'Finnish values' with the values of the church. With regard to the first, I quote Räsänen again:

Quickly going through this list, it seems like just about the only things that are forgotten is a proposal to abandon the flag with the blue cross, and changing religious holidays into working days. In my opinion, the best part of this bill is its short list of signatories.

There are at least two things going on here. First, Räsänen draws a connection between the status of the church and the national symbol, the Finnish flag. Second, she uses populist rhetoric that implies people would need to work more 
days in a year if the initiative was to pass - a point significant even for people indifferent to the status of the church. The reason she is able to presuppose that the church and flag go hand in hand for many if not all MPs is the idea of 'home, religion and fatherland' (koti, uskonto ja isänmaa), which according to Virkkunen (1981, 207) 'were the central Finnish values between the world wars'. The saying was popularised by the Finnish arch-hero Marshal Mannerheim's widely publicised speech on his assumption of the command of the Finnish forces when hostilities with the Soviet Union broke out in late 1939, where he said that 'we fight for home, religion and fatherland' (Virkkunen 1981, 207). This discourse, although diminished after the Second World War, is deeply ingrained in Finnish public discourse and Räsänen is able to intertextually (Fairclough 1992, 101-136) exploit it in her defence of the church.

In addition to symbolic rhetoric, the idea of a 'folk' church is constructed by Räsänen and others also by what could be called the 'democratic' argument. In her opening response Räsänen says that 'in legislative work, it is justified to take into consideration the prevailing religious circumstances (olot). It is justified for a religious community's legal status to reflect the community's real status in society, and this is how democracy works' (emphasis added). She goes on to point out that 84 percent of Finns belong to the church and of them 73 percent have never considered leaving the church. The juridical status of the Lutheran Church reflects the religious situation in the country and its religious-cultural history. Finally, she repeats the argument in her closing statement: 'Based simply on the principles of democracy, it is quite right that the influence of Christian values, Christian cultural heritage is visible' (emphasis added).

Although the 'folk' church discourse is only one and not necessarily the most significant in Räsänen's repertoire, it is the one that sets the tone for much of the rest of the discussion. So we have, for example, Lauri Oinonen, a Centre Party MP and Lutheran minister from rural Multia ${ }^{12}$ arguing that:

Therefore, the laws are in harmony with the fact that citizens, who are both citizens of the state, inhabitants of municipalities and mostly members of the Evangelical Lutheran Church, can live with a legislation which is in harmony with itself.

Centre party colleague Simo Rundgren, also a Lutheran minister, from Kolari in Lapland, puts the same thing bluntly when defending religious education in state-funded schools: 'About 85 percent of Finns belong to the Lutheran Church [...] This is just the way our will is.'

The third way in which the status of the church as a 'folk' church is justified equates 'Finnish values' with a Christian heritage in general and the Lutheran Church (to a lesser degree with the Orthodox Church) in particular. Esa Lahtela, a Social Democrat from rural Kitee, who closes his first response by saying that the initiative should be thrown into the dustbin, argues:

First of all, the whole Finnish society is in any case built on this Christian value base. From that one could of course immediately say that when in Rome, do as

\footnotetext{
${ }^{12}$ Traditionally, the Greens and the Left Alliance especially, but also urban politicians (e.g., Helsinki's Krohn and Tampere's Meriläinen) in general have been more critical of the status quo, whereas strongest support for the current legislation comes from the Christian Democrats and rural MPs (especially in the Centre Party). Hence the references to the MPs' home constituencies here.
} 
the Romans do (maassa maan tavalla), which means that certain foundations have existed. Our legislation is built on a particular value base and it draws its strength from these values, which come from Biblical doctrines, Christian doctrine.

In an age of global immigration, the idea of 'when in Rome ...' is controversial, to say the least. But perhaps more interestingly, for Lahtela, legislation 'is built' on Christian values, but in this case no one is doing the building. The human actions, the debates and struggles that created the legislation in the first place disappear and the putative Christian value base is naturalised as an essential characteristic of Finnish society, which in turn supports the 'folk' church discourse. This is in stark contrast to, for example, the seemingly endless debates in the United States about the 'original intent' of the Founding Fathers, especially regarding the second amendment (e.g., Davis 2000; McGraw 2003).

Social Democrat MP Kalevi Olin from Jyväskylä in central Finland, echoes the sentiment:

That equality is realized is surely a modern aspiration, but, dear Mister Speaker, according to research the success of Finnish society, for example in working life, is based on exactly the Protestant ethic, especially in agricultural society, but also in industrial, on work ethic and in this case it is worth asking whether there is reason to abandon this kind of Lutheran viewpoint.

For Olin, the matter is not simply taking the essentially Christian culture at face value. Instead, this is so 'according to research' (or 'studies'). The issue is therefore not a matter of personal preference, but something that is scientifically backed.

Perhaps the most significant blow to the initiative comes from Krohn's Green colleague Erkki Pulliainen from the northern city of Oulu, who again repeats the fundamental role that Christian heritage has for the Finns:

Values belong to Finnish society as a very important element. Those particular values, specifically Christian values, whether they are realised (toteutuivatpa ne) in the Evangelical-Lutheran Church or the Orthodox Church, are very important things. They are downright ultimate things.

Pulliainen also does what the others do less explicitly when arguing about the Christian value heritage, that is, he equates the value base with the two 'folk' churches (where the values are realised). By doing so his and the others' responses switch the focus of discussion from a question of religious equality to a question of national identity.

\section{Pluralism and the church as a value base}

Issues of national identity are also at stake in the fourth type of discourse that I have named the 'pluralism' discourse. This discourse is also concerned with values, but whereas the naturalisation of the 'folk church' as the cultural carrier of putatively essential Finnish values is a backward-looking discourse, the pluralism discourse looks forward in a situation of increasing religious diversity.

MP Räsänen again hints at this discourse by stating in her opening speech that 'it has to be admitted that the way in which religions and worldviews really have an important cultural significance is brought up with distinction in this initiative.' But, whereas the initiative argued that 'strengthening religious equality increases trust in the public authorities, improves social harmony, helps the adjustment of 
immigrants into our country and increases the attraction of Finland in the eyes of foreign professionals' (LA 157/2005 vp), Räsänen sees things differently. Just the previous day the public prosecutor in Finland had decided to open up an investigation into Suomen Sisu after the organisation published the controversial Danish Mohammed cartoons on their website. Now Räsänen asks 'in the eyes of what kind of foreign professionals would the attraction of Finland be increased' if the initiative's proposal to get rid of blasphemy laws would be accepted.

The pan-Nordic (or rather, pan-European) crisis over the cartoons works as a springboard for elaborations that go beyond the legislation at issue. Again, beyond Räsänen's initial remark above, the discourse does not even directly address the initiative's legislative points, but rather answer to an assumed attack against the 'folk' church. This time, however, the point is not so much about retaining essential cultural values, but arguing that Finns need Christian values - which are 'realised' in the church - in order to cope with religious diversity. So, for example, Centre Party MP Rundgren says that:

First I would now say here that the more the world is globalised, internationalised, and we meet with a variety of cultures, the bigger challenge it is for us to take care of this worldview and religious education and upbringing in our own country. The knowledge of our own roots, our own tradition, the knowledge of our own religion is in my opinion the best way toward building peace, toward creating a climate of tolerance and agreement in the whole world.

The same theme had already been taken up by another Centre Party MP Oinonen:

I think that, contrary to what is presented in the bill, the Christian vision of life in Finland should be strengthened. For example, it has been said by Muslims that if Finns were more Christian and better Christians, then it would be better for Muslims to live in this country. I hope that they live well also now, and so I believe they also feel, but they feel that if the people of this country were more Christian, then that would be good for everyone else as well.

Notably, no individual Muslim or Muslim organisation comes forth in Oinonen's passive formulation. The broader point that the more the Finns are anchored in Christian values, the better they are equipped to deal with religious diversity and to be tolerant, is repeated by others, including Krohn's Green League colleague Erkki Pulliainen. The presupposition, which is constructed by transitively masking the actor and modally (in Oinonen's case) by distancing the speaker from the opinion, is that more religion equals more religious tolerance. Because, as the 'folk' church discourse made clear, being Christian in Finland more or less equals being Lutheran, retaining the role of the church is supported both explicitly and implicitly.

\section{Conclusion: Believing in belonging?}

In the above, I have identified four discourses in the preliminary debate on the LA $157 / 2005 \mathrm{vp}$ initiative. The analysis shows that while the purpose of the bill was, as Krohn also reminds her fellow MPs in her second response, to discuss 'where the place of religion and faith is relation to public authority', the debate soon branches into fundamental issues of national identity. The legislative struggle is fought between the signatories' original inequality discourse and the 'complete' freedom of religion discourse of MP Räsänen, especially. Räsänen's 'minimalist' discourse 
might as well be called a liberal definition, because according to it, freedom of religion is 'complete' when it guarantees religious freedom to the individual - an argument that Seppo (2003) explicitly makes - regardless of unequal treatment of religious communities. This of course leads to long-standing debates about multiculturalism and the rights of individuals versus the rights of communities.

Those debates are not, however, at the heart of the discussion on the LA 157/2005 vp initiative. Instead, the legislative details of the initiative play second fiddle to what is interpreted by most of the discussants as an attack against the church, and by extension, against Finnishness. This, in turn, is seen as a hopeless cause, as witnessed by the condescending remarks towards MP Krohn by the other MPs. Päivi Räsänen says that: 'MP Krohn has many wise ideas and also some good political aims, and I even feel a little bit sorry for you for having to defend this initiative by yourself, without any support from the floor.' Indeed, the then leader of the Greens emphasises in her response that this was not a party initiative. Finally, the speaker had to remind MP Rundgren that it is against the parliamentary code of conduct to use the singular 'you' (sinä) or refer to other MPs using their first names, after Rundgren had referred to Krohn as 'sinä, Irina'.

The variety and type of discourses, and what plausible political choices are enabled by those discourses is one interesting aspect of the analysis. But the absence of any type of discourse on behalf of the vast majority of Finnish MPs is another. This has two important implications. First, methodologically, the context matters: it is not only what is said that matters, but also what is not said. Second, empirically speaking, what emerges from the legislative discourse in this case is what I call - following American essayist Joan Didion - 'national piety'. In the opening epigraph Didion talks about 'fixed opinions' and a 'screen that slides into place whenever actual discussion threatens to surface'. Although speaking of public discourse in post-9/11 America, Didion's words ring true for the issue of religious equality in Finnish parliamentary discourse in the early 21st century. National piety, as used here, refers to both active and passive support for the status quo. This should be differentiated from 'civil religion', however. In the Finnish context, Bellah's (1967) original formulation of a non-denominational civil religion has been interpreted so that the Lutheran Church becomes an inseparable part of Finnish civil religion (e.g., Sundback 1984). Whether that assessment is correct or not is a sociological question. 'National piety', by contrast, is the ideological discourse - and silence - that legitimates the privileged status of the Lutheran Church. ${ }^{13}$

The crushing opposition to the initiative, and even more importantly, the silence of the majority of the MPs on the subject indicates that there is an overwhelming consensus about the fact that if legislation on religious equality or freedom of religion threatens the church-state status quo, it is a topic which should be left alone in parliamentary discussion. In other words, the bill was 'clammed up dead' as the Finnish saying goes. To use a well-known expression from the sociology of religion (Davie 1994): those who opposed the bill on the grounds of the importance of the church as a spiritual pillar of society are clearly 'believing and belonging'. And, judging from their hesitancy to even take part in the discussion, although their

\footnotetext{
${ }^{13}$ It should be noted that 'civil religion' can be used for ideological purposes, of course (and, some would argue, has been so used). The distinction here is analytical, the actual uses murkier. 'Civil religion' was discussed mostly in the 1980s in Finland (Lampinen 1984; Sundback 1984) and, as the LA 157/2005 vp discussion attests, has not 'trickled down' to everyday use.
} 
silence gives little clue as to what their position in the issue is, the great silent majority can be said at least to be 'believing in belonging' (cf. Davie 2000, 3; Day 2011; Voas and Crockett 2005). Davie's other, perhaps less known, concept of 'vicarious religion' - 'religion performed by an active minority but on behalf of a much larger number, who (implicitly at least) not only understand, but, quite clearly approve of what the minority is doing $(2007,22-23)$ - also reflects some aspects of this dynamic. Whatever one thinks of the broader uses of the term, in the context of parliamentary debate, it can be useful. First, the Finnish MPs opposing the LA 157/2005 vp initiative served a vicarious function by reproducing the status quo. Second, by virtue of their silence the 192 MPs who did not take part in the debate - their individual preferences notwithstanding - can be interpreted to have (at least implicitly) understood and even approved what the vocal minority was doing. My argument, of course, is that it is the discourse itself that creates this vicariousness. As long as the discourse keeps reproducing the status quo, the putative values that Davie seems to assume as the source of vicariousness are secondary.

Analytically, there might be good reasons 'to separate the issue of religious freedom from the church-state relationship rather than using it as an indicator' (Minkenberg 2003, 198). Empirically, however, neat boundaries between the two are muddled, as LA 157/2005 shows. In May 2006, just three months after the analysed plenary debate, the Greens decided to include the separation of church and state in their election programme. The comment of Green MP Tuija Brax is exemplary of these fuzzy boundaries (and internal party divisions regarding the issue). The Helsinki-based Church of Finland weekly newspaper Kirkko ja Kaupunki wrote the following:

Tuija Brax suspects that there is some ignorance in the Greens' decision about the fact that Finland doesn't have a state church but a folk church. The Finnish Freedom of Religion Act has also received acclaim in international comparisons. 'Not everyone knows that the special relationship between the state and the church is limited only to a couple of factors.' (Kytöharju 2006)

It is impossible to say whether the point about the favourable image of Finnish freedom of religion legislation in international comparison is Brax's or the author's comment, but in any case this is a good example of the conflation of these issues. So, not only is freedom of religion closely related to church-state issues empirically, but it is also the task of critical sociology of religion to interrogate situations where the analytical separation is muddled in an ideological way - as in the current case where the hegemonic political discourse in Finland represents the state church and the 'folk' church as separate entities, and by doing so uses the latter to reproduce the former.

Further, if we only look at the outcomes of parliamentary discourse, that is, the constitution and current law, we miss a point about 'political secularisation' that is not obvious from a macro perspective. This is the secularisation of the political discourse itself. As I have argued above, the 'folk' church discourse may be used to reproduce an 'active state religion' (Fox 2008, 114-116), but the ways in which this is accomplished are increasingly secular: we find constitutional and legal arguments, appeals to tradition and common values - national identity - but little in terms of explicit religious discourse (cf. Bruce 2011, 171). In the Finnish case, 'national piety' enables the continued privileged position of the Lutheran and Orthodox churches, but a religious revival in politics it is not. 
Titus Hjelm is Lecturer in Finnish Society and Culture at University College London. His main areas of expertise are sociology of religion, social problems, social theory, media and popular culture. His recent publications include Religion and Social Problems (ed., Routledge, 2011), Studying Religion and Society: Sociological Self-Portraits (ed. with Phil Zuckerman, Routledge, 2013) and a special issue of the Journal of Religion in Europe on Islam in European news media (2012). In addition, he has published several books in Finnish and articles in journals such as Social Compass and Journal of Contemporary Religion. He is the co-editor of the Journal of Religion in Europe (published by Brill) and the founding chair of the American Academy of Religion's Sociology of Religion Group.

\section{Acknowledegments}

I would like to thank the five anonymous referees for their clarifying comments and suggestions. All remaining mistakes are my sole responsibility, of course.

\section{References}

Anderson, K. M. 2009. “The Church as Nation? The Role of Religion in the Development of the Swedish Welfare State." In Religion, Class Coalitions, and Welfare States. Kindle Edition. edited by van Kersbergen and Manow. Cambridge: Cambridge University Press.

Barbalet, J., A. Possamai, and B. Turner, eds. 2011. Religion and the State: A Comparative Sociology. London: Anthem Press.

Bellah, R. N. 1967. “Civil Religion in America." Daedalus 96 (1): 1-21.

Bruce, S. 2011. Secularization: In Defence of an Unfashionable Theory. Oxford: Oxford University Press.

Burns, R., M. Constable, J. Richland, and W. Sullivan. 2008. "Analyzing the Trial: Interdisciplinary Methods." PoLAR: Political and Legal Anthropology Review 31 (2): 303-329.

Burr, V. 1995. Introduction to Social Constructionism. London: Routledge.

Chaves, M., and D. E. Cann. 1992. "Regulation, Pluralism, and Religious Market Structure: Explaining Religion's Vitality." Rationality and Society 4 (3): 272-290.

Chouliaraki, L., and N. Fairclough. 1999. Discourse in Late Modernity. Edinburgh: Edinburgh University Press.

Christensen, E. 1995. "Is the Lutheran Church Still the State Church? An Analysis of Church-State Relations in Finland." Brigham Young University Law Review 1995 (2): 585-601.

Davie, G. 1994. Religion in Britain Since 1945: Believing without Belonging. Oxford: Blackwell.

Davie, G. 2000. Religion in Modern Europe: A Memory Mutates. Oxford: Oxford University Press.

Davie, G. 2007. "Vicarious Religion: A Methodological Challenge." In Everyday Religion: Observing Modern Religious Lives, edited by N. T. Ammerman, 21-35. Oxford: Oxford University Press.

Davis, D. H. 2000. Religion and the Continental Congress 1774-1789: Contributions to Original Intent. New York: Oxford University Press.

Davis, D. H. 2011. "George W. Bush and Church-State Partnerships to Administer Social Service Programs: Cautions and Concerns." In Religion and Social Problems, edited by T. Hjelm, 186-197. New York: Routledge.

Day, A. 2011. Believing in Belonging: Belief and Social Identity in the Modern World. Oxford: Oxford University Press.

Didion, J. 2003. Fixed Ideas: America since 9.11. New York: New York Review of Books.

van Dijk, T. A. 1997. "Political Discourse and Racism: Describing Others in Western Parliaments." In The Language and Politics of Exclusion: Others in Discourse, edited by S. H. Riggins, 31-64. Thousand Oaks, CA: Sage.

Fairclough, N. 1989. Language and Power. London: Longman.

Fairclough, N. 1992. Discourse and Social Change. Oxford: Polity Press.

Fairclough, N. 1995. Critical Discourse Analysis. London: Longman.

Fairclough, N., and I. Fairclough. 2012. Political Discourse Analysis. Kindle edition. London: Routledge.

Fox, J. 2008. A World Survey of Religion and the State. Cambridge: Cambridge University Press.

Goffman, E. 1981. Forms of Talk. Oxford: Basil Blackwell. 
Granholm, K. 2013. “Esoteric Currents as Discursive Complexes.” Religion 43 (1): 46-69.

Gustafsson, G. 2003. "Church-State Separation Swedish-Style." West European Politics 26 (1): 51-72.

Heikkilä, M., J. Knuutila, and M. Scheinin. 2005. "State and Church in Finland." In State and Church in the European Union. 2nd ed. edited by G. Robbers, 519-536. Baden-Baden: Nomos.

Juva, M. 1960. Valtiokirkosta kansankirkoksi. Helsinki: Suomen Kirkkohistoriallinen Seura.

Krohn, I. 2006. “Tiedote 15.2.2006." Accessed July 14, 2012. http://www.vihreat.fi/yleviarkisto/2_2006/ 0045.html

Kytöharju, M. 2006. “Vihreä kiila kirkon ja valtion suhteessa.” Kirkko ja Kaupunki, 5 June 2006. Accessed July 14, 2012. http://www.kirkkojakaupunki.fi/arkisto/uutiset-ja-ilmiot/2835/

LA 157/2005. 2005. "Laki Suomen perustuslain 76 §:n kumoamisesta sekä eräiden siihen liittyvien lakien kumoamisesta ja muuttamisesta." Accessed July 14, 2012. http:/www.eduskunta.fi/faktatmp/ utatmp/akxtmp/la_157_2005_p.shtml

Lampinen, T. 1984. "Preaching of State - Civil Religion in the Proclamation of Church and State in Finland." In The Church and Civil Religion in the Nordic Countries of Europe, edited by B. Harmati, 41-48. Geneva: Lutheran World Federation.

Lincoln, B. 2003. Holy Terrors: Thinking About Religion After September 11. Chicago: The University of Chicago Press.

McGraw, B. 2003. Rediscovering America's Sacred Ground: Public Religion and Pursuit of the Good in a Pluralistic America. Albany: State University of New York Press.

McKinnon, A. 2012. "Ideology and the Market Metaphor in Rational Choice Theory of Religion: A Rhetorical Critique of 'Religious Economies'." Critical Sociology Published Online 2 May 2012. doi:10.1177/0896920511415431.

MichelP., and E. Pace, eds. 2011. Annual Review of the Sociology of Religion, vol. 2: Religion and Politics. Leiden: Brill.

Minkenberg, M. 2003. "The Policy Impact of Church-State Relations: Family Policy and Abortion in Britain, France, and Germany." West European Politics 26 (1): 195-217.

Moberg, M. 2013. "First-, Second-, and Third-level Discourse Analytic Approaches in the Study of Religion: Moving from Meta-theoretical Reflection to Implementation in Practice." Religion 43 (1): 1-22.

Monsma, S. V., and J. C. Soper. 2009. The Challenge of Pluralism: Church and State in Five Democracies. 2nd ed. Lanham, MD: Rowman and Littlefield.

Palonen, K. 2008. "Speaking Pro et Contra: The Rhetorical Intelligibility of Parliamentary Politics and the Political Intelligibility of Parliamentary Rhetoric." In The Parliamentary Style of Politics, edited by S. Soininen and T. Turkka, 82-105. Helsinki: The Finnish Political Science Association.

Pekonen, K. 2008. "Two Versions of Representative Talk in Finnish Parliament." In The Parliamentary Style of Politics, edited by S. Soininen and T. Turkka, 208-227. Helsinki: The Finnish Political Science Association.

Phillips, N., and C. Hardy. 2002. Discourse Analysis: Investigating Processes of Social Construction. Sage University Papers Series on Qualitative Research Methods, vol. 50. Thousand Oaks, CA: Sage.

Potter, J. 1996. Representing Reality: Discourse, Rhetoric, and Social Construction. London: Sage.

Reisigl, M. 2008. "Analysing Political Rhetoric." In Qualitative Discourse Analysis in the Social Sciences, edited by R. Wodak and M. Krzyzanowski, 96-120. Basingstoke: Palgrave.

Richardson, J. E. 2007. Analysing Newspapers: An Approach from Critical Discourse Analysis. Basingstoke: Palgrave.

Robbers, G. 2005. "State and Church in the European Union." In State and Church in the European Union. 2nd ed. edited by G. Robbers, 577-589. Baden-Baden: Nomos.

Seppo, J. 1998. "The Freedom of Religion and Conscience in Finland." Journal of Church and State 40 (4): 847-872.

Seppo, J. 2003. “Die Religionsfreiheit im Spiegel des Staat-Kirche-Verhältnisses in Finnland.” Studia Theologica - Nordic Journal of Theology 57 (1): 20-35.

Sihvo, J. 1991. "The Evangelical-Lutheran State and the Church in Finland." Social Compass 38 (1): 17-24. von Stuckrad, K. 2010. "Reflections on the Limits of Reflection: An Invitation to the Discursive Study of Religion." Method and Theory in the Study of Religion 22 (2/3): 156-169.

Sullivan, W. F. 2005. The Impossibility of Religious Freedom. Princeton, NJ: Princeton University Press.

Sundback, S. 1984. "Folk Church Religion - A New Kind of Civil Religion?." In The Church and Civil Religion in the Nordic Countries of Europe, edited by B. Harmati, 35-40. Geneva: Lutheran World Federation.

Taira, T. 2013. “Making Space for Discursive Study in Religious Studies.” Religion 43 (1): $26-45$.

Thompson, J. B. 1990. Ideology and Modern Culture. Stanford: Stanford University Press. 
Turner, B., A. Possamai, and J. Barbalet. 2011. "States, Consumption and Managing Religions." In Religion and the State: A Comparative Sociology, edited by J. Barbalet, A. Possamai, and B. Turner, 1-22. London: Anthem Press.

Virkkunen, S. 1981. Suomalainen fraasisanakirja. Helsinki: Otava.

Voas, D., and A. Crockett. 2005. "Religion in Britain: Neither Belonging nor Believing." Sociology 39 (1): 11-28.

Wijsen, F. 2013. “There are Radical Muslims and Normal Muslims': An Analysis of the Discourse on Islamic Extremism." Religion 43 (1): 70-88.

Wodak, R. 2008. "Introduction: Discourse Studies - Important Concepts and Terms." In Qualitative Discourse Analysis in the Social Sciences, edited by R. Wodak and M. Krzyzanowski, 1-29. Basingstoke: Palgrave.

Submitted: January 31, 2013

Revised version Submitted: April 16, 2013, June 21, 2013, August 10, 2013,

September 17, 2013

Accepted: September 22, 2013 